\title{
ANÁLISIS
}

\section{Mexico in Asia Pacific: Lagging Competitiveness and Lacking Reform}

DOI: $10.32870 /$ mycp.v13i37.335

José Gerardo Traslosheros Hernández ${ }^{1}$

\section{Summary}

$\mathrm{M}$ exico has traditionally shown an ambivalent attitude towards the Asia Pacific region and the Asia Pacific Economic Cooperation (APEC) in particular. This sentiment has been driven mainly by the attitude of its private sector, which perceives the region much more as a threat than as an opportunity. Mexico's vicinity with the US, the growing dependence of imports from Asia, and the need to urgently conduct domestic reforms, force Mexico to become fully engaged in APEC initiatives.

However, Mexico remains at an impasse internally, being unable to take the decisions to embark in the search for markets in Asia and conduct its domestic reforms. In the meantime, the rest of the world keeps moving ahead

1. Professor and Researcher at Instituto Tecnológico y de Estudios Superiores de Monterrey, Campus Ciudad de México. The author has been Mexico's Senior Official representative at the Senior Officials Meetings in APEC (known as the SOM), and was Chairman of the SOM in APEC Mexico 2002. The Article draws on the authors experience as former Director General in charge of Asia Pacific Affairs at the Ministry of the Economy of Mexico. This document has greatly benefited from comments received during a Workshop Organized by the Universidad de Guadalajara and the World Universities Network in January of this year, and from comments by two anonymous referees. The author is grateful for the able assistance of Sergio Zúñiga, Liliana Témix and Itzel Maldonado. All remaining errors are the authors own fault. ORCID http://orcid.org/0000-0003-1525-9907 
and greater integration in East Asia keeps taking place leaving Mexico out of business opportunities.

The key impediments to advance Mexico's competitiveness and market liberalization agendas are to be found in the domestic political economy, which remains the key obstacle to pursue a more aggressive agenda in Asia Pacific and elsewhere. Although APEC's potential has been generally oversold by its members and thus its credibility has been hampered, through an appropriate perspective of what APEC is capable of doing and what it is not, the Mexican Government could and should make much more active use of its membership, as it does with other international organizations such as the Organization for Economic Cooperation and Development (the OECD), to push for greater reform at home and further market opening both at home and abroad.

\section{Introduction}

Mexico has traditionally shown an ambivalent attitude towards the Asia Pacific region and APEC in particular. This sentiment has been driven mainly by the attitude of its private sector which perceives the region much more as a threat than as an opportunity. Mexico is a member of APEC much more by political necessity and geographical accident than by conviction. Its position in APEC has tended to be rather defensive. Mexico's vicinity with the US and the growing dependence of imports from Asia for intermediate goods to boost its exports to the US market, are sufficient reasons for Mexico to become an actively engaged member within APEC.

Nowadays the Mexican private sector remains adamantly opposed to any trade negotiation initiative within the region (and generally elsewhere), while the Mexican Government remains unable to begin negotiations without the consent from the private sector. Depending on each particular case, the underlying reason for the opposition of the private sector is the lack of adequate competitive conditions domestically and the corresponding fear of exposing the domestic industries to competition from countries with a similar or more advanced stage of economic development in sectors such as chemicals, textiles, garments, footwear, steel, automobiles, electronics and others. A related argument is that Mexico has not been able to reap the benefits of its extensive array of FTAs.

Mexico thus remains at an impasse internally, being unable to take the relevant domestic decisions to embark in the search for markets in Asia and 
to conduct its domestic structural reforms ${ }^{2}$. In the meantime, the rest of the world keeps moving ahead, and greater integration in East Asia keeps taking place. Mexico is clearly being left out of business opportunities around the globe, thereby increasing its relative dependency on the US market.

This article analyzes the nature of the trade relationship between Mexico and APEC members, highlights the present conundrums in Mexico's tariff structure, and uses the competitiveness indexes of the World Economic Forum to compare Mexico with a sample of countries including key associates in $\mathrm{APEC}^{3}$. It also briefly reviews APEC's agenda on Structural Reform and on a possible Free Trade Agreement in the Asia Pacific (FTAAP), emphasizing the coincidences with Mexico's own agenda and suggesting possible courses of action. A corollary is that there is sufficient space for Mexico to become a much more enthusiastic, aggressive and active member of APEC.

The key impediments to advance Mexico's competitiveness and market liberalization agendas are to be found in the domestic political economy, which remains the key obstacle to pursue a more aggressive agenda in APEC and elsewhere. APEC remains very much alive as a key forum as testified by the unfailing attendance every year by practically all regional heads of State and Government (known in the APEC jargon as the Economic Leaders).

Although APEC's potential has been oversold across the region by many of its members and thus its credibility has been somewhat hampered, through an appropriate fine tuning of what APEC is capable of doing and what it is not, the Mexican Government could and should make much broader and more active use of its membership in APEC, as it does with other international organizations, to push for greater reform at home and further market opening both at home and abroad.

2. Structural reform is referred to as major changes in laws, regulations and institutions governing a specific sector or market such as labor, energy, telecom, competition policy, regulatory burdens, and the like, so as to improve their functioning and thus benefit the competitiveness of the rest of the economy. By competitiveness it is understood simply as the capacity to compete succesfully in world markets.

3. The sample used includes some non APEC developed and emerging countries so as to be able to compare with other important players. 


\section{The Trade Relationship between Mexico and Asia}

On January $1^{\text {st }}$, 2010, the Free Trade Agreement (FTA) between the Association of South East Asian Nations (ASEAN), Australia and New Zealand entered into force. On that same date, the last phase of the implementation of the tariff liberalization agreed in the China - ASEAN Free Trade Agreement between China and the six more advanced nations of ASEAN took place (Brunei, Philippines, Indonesia, Malaysia, Singapore and Thailand). ASEAN has also concluded the negotiation of FTAs with Japan, South Korea and India.

According with the World Trade Organization, in 2008 the FTA between China and ASEAN represented the third largest trading block in the world (3 percent of world trade). The two other larger trading blocks were the European Union (25 percent) and NAFTA (6 percent). ${ }^{4}$

Another important trade initiative, perhaps more by its significance as a true bridge between the two sides of the Pacific than by its present trade size, is the Trans-Pacific Strategic Economic Partnership, which is a comprehensive agreement signed by New Zealand, Chile, Singapore and Brunei and which entered into force in 2006. This is an agreement open to new members be it from APEC or elsewhere. As of today, Australia, Peru, Japan and Vietnam have expressed their willingness to join the Transpacific Partnership, and the present US administration quite recently expressed its willingness to engage in such an arrangement. ${ }^{5}$

Clearly, as the integration process continues in East Asia and across the Pacific, Mexican exporters, both current and potential, are being left out of export opportunities in the region. In the near future East Asia's trade negotiating agenda will erode Mexican market preferences everywhere.

While this market opening takes place in the Asia Pacific, as a consequence of the proliferation of the Mexican Free Trade Agreements (FTAs) as well as numerous internal customs arrangements and programs (a number of them meant to enhance the competitiveness of domestic industries and promote exports), Mexico's customs administration has become a real puzzle and unmanageable nightmare.

4. See for example Inteligencia Comercial (IQOM), “Continúan países de Asia Proceso de Integración Comercial: México se mantiene al margen”, January 2010, in the references to this article.

5. See Barfield, Claude and Phillip I Levy, January 2010, in the references to this article. 
This has become an unsustainable situation that has practically forced the Government to impose on its productive sector a unilateral trade liberalization agenda on an MFN basis, which was officially announced without the private sector consent through a presidential decree in December of 2008 by the Mexican Government. The program was immediately repudiated by the private sector and has contributed to the creation of a rather tense relationship between the Private Sector and the Administration of President Felipe Calderón.

The view maintained in this article is that the Government should not abandon its announced unilateral liberalization program. On the contrary, it should pursue such program, but in order to sustain it, the Government must necessarily couple market opening with a strategic plan to accomplish the pending domestic structural reforms, which of course requires at a minimum the involvement of the legislative and the private sector. Otherwise, the domestic industry will increase its political pressure to abort the unilateral liberalization program, something which could happen in a few years

Clearly, as the integration process continues in East Asia and across the Pacific, Mexican exporters, both current and potential, are being left out of export opportunities in the region. In the near future East Asia's trade negotiating agenda will erode Mexican market preferences everywhere time. Unfortunately, such strategic plan involving all relevant actors seems still far away. Domestic politics interfere and political parties as well as domestic actors continue blocking the needed reforms.

At the same time, and consistently with its own agenda of unilateral market opening, Mexico should pursue a much more aggressive export penetration policy in Asia Pacific, seeking the reduction of barriers to its products in the same manner as other more open economies like Australia, New Zealand and Chile have been doing for the last decade.

To date, Mexico has subscribed only one FTA in Asia, namely with Japan, which entered into force on April 2005. In February 2006, Mexico initiated negotiations for an FTA with South Korea. However, the negotiation was abandoned due to the opposition of the Mexican manufacturing sector. 
Another negotiation attempt was aborted in 2001 with Singapore, again due to the opposition of the Mexican private sector. Bilateral studies have been completed recommending the negotiation of FTAs with Australia and New Zealand, but no go ahead has been given to start the negotiating process again due to the resistance of private interest.

On the Latin American negotiating front, during the present administration of President Felipe Calderón, it has not been possible to conclude negotiations either with Peru or Panama. A possible FTA with Brazil is looming in the horizon under strong resistance by the private sector once again. In recent days President Calderón and President Lula announced the negotiation of a Strategic Economic Association Agreement, which is meant to include an FTA but there is widespread opposition in Mexico to the said agreement once again.

It is a curious how domestic economic policy is being conducted nowadays. While the federal Government has imposed a unilateral market opening program to the private sector without a strategic plan to conduct domestic reforms, it is not capable of engaging in the negotiations of FTAs to try to open foreign markets in a reciprocal manner.

ASEAN has not been a significant trading partner for Mexico, representing only around 2 percent of total Mexican trade (see table 1). In 2008, imports from ASEAN represented over 11.5 billion dollars, while Mexican exports amounted only to 870 million. Malaysia sold over 4.6 billion to Mexico while half of Mexican exports had Singapore as a destination.

Table 1

Participation in Mexican Trade

\begin{tabular}{lrr}
\hline Year & 2007 & 2008 \\
\hline ASEAN & $2 \%$ & $2 \%$ \\
China & $6 \%$ & $6 \%$ \\
Australia & $0.20 \%$ & $0.20 \%$ \\
New Zealand & $0.10 \%$ & $0.10 \%$ \\
\hline
\end{tabular}

Source: IQOM.

China is the Asian country with which Mexico has the most intense trade relation (6 percent of its total trade). Australia and New Zealand together account for not more that $0.3 \%$ of total Mexican trade. As a region, Asia today is Mexico's second most important trade relationship and above Europe, due to the increasing importance of China in world trade (see figure 1). 
Figure 1

Mexican Trade by Region in percentages

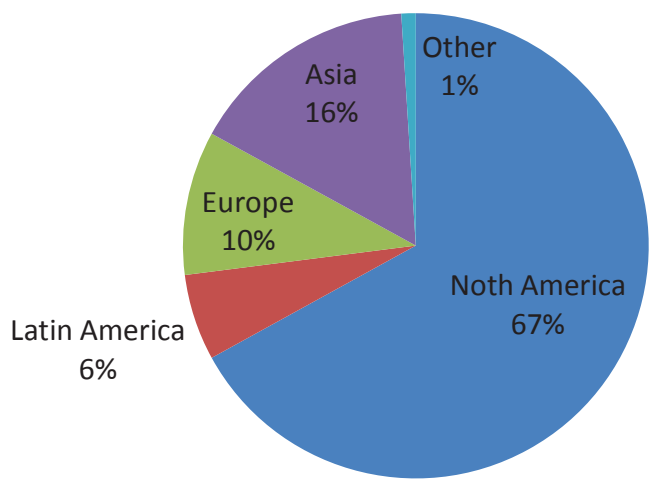

Source: IQOM.

If we analyze the changes in the composition (or structure) of trade by region, we notice that in 2007 close to 15 percent of Mexico's total trade took place with Asia and Oceania. Four of the main trading partners of Mexico belong to East Asia and add up to 12 percent of Mexican total trade. Only 1.6 percent of Foreign Direct Investment (FDI) into Mexico came from that region between 1999 and 2007 (2.9 US billion). ${ }^{6}$

Mexico's export structure has remained relatively stable since the implementation of the NAFTA (see table 2) ${ }^{7}$. Since then, there was an important change in the import structure of Mexico in favor of Asia (see table 3), which has also been associated with a mounting trade deficit against that region.

6. This percentage does not take into account the investment by subsidiaries of Asian companies based in the United States.

7. However, it must be noticed that it is likely that Mexican export figures do not accurately reflect the true destiny of our exports, since the final country of destination is somewhat difficult to obtain in the export data. It would be more appropriate to measure our exports by the imports of the final destination where goods are finally consumed or substantially transformed into other goods. 
Table 2

Mexican Export Structure by Region. US billion

\begin{tabular}{lrcrcr}
\hline & 1993 & Percentage & 2007 & Percentage & Growth 93/07 \\
\hline Total & 51.7 & 100 & 272.1 & 100 & 426.3 \\
North America & 44.4 & 85.7 & 229.9 & 84.5 & 417.8 \\
Latin America and the Caribbean & 2.9 & 5.6 & 18.3 & 6.7 & 531 \\
Asia and Oceania & 1.2 & 2.3 & 7.5 & 2.8 & 525 \\
Europe & 2.9 & 5.7 & 14.7 & 5.4 & 406.9 \\
Rest of the World & 0.3 & 0.6 & 1.7 & 0.6 & 466.7 \\
\hline
\end{tabular}

Source: Ministry of the Economy.

Table 3

Mexican Import Structure by Region. US billion

\begin{tabular}{lrrrrc}
\hline & 1993 & Percentage & 2007 & Percentage & Growth 93/07 \\
\hline Total & 65.3 & 100 & 283.2 & 100 & 333.7 \\
North America & 46.5 & 71.2 & 148.5 & 52.4 & 219.4 \\
Latin America and the Caribbean & 2.6 & 3.9 & 15.9 & 5.6 & 511.5 \\
Asia and Oceania & 7.6 & 11.6 & 79.7 & 28.1 & 948.7 \\
Europe & 8.5 & 13.1 & 36.5 & 12.9 & 329.4 \\
Rest of the World & 0.1 & 0.2 & 2.6 & 0.9 & 2500 \\
\hline
\end{tabular}

Source: Ministry of the Economy

While the Mexican trade deficit with Asia has exploded since the implementation of NAFTA, the Mexican surplus with the United States has also impressively increased (see graphs 1 and 2). The Mexican export boom to the United States can be explained by factors such as the market opportunities opened up by NAFTA and the behavior of the real value of the peso against the dollar after the "tequila crisis" in the mid 90s.

Another related explanation is the reorganization of labor that followed the implementation of the NAFTA, which to an important extent founded the competitiveness of Mexican exports on the strength of traditional "maquiladora" type operations (such as in the electronics industry). More importantly, the lack of a world quality Mexican parts and components supporting industry implied an important increase in imports of intermediate goods from Asia to respond to the expanded market access opportunities which occurred since 1994 (see Graph 3). 


\section{Graph 1}

Mexican Trade Deficit Against Asia and Oceania

(US Millions)

$$
\text { Exports I Imports Deficit }
$$

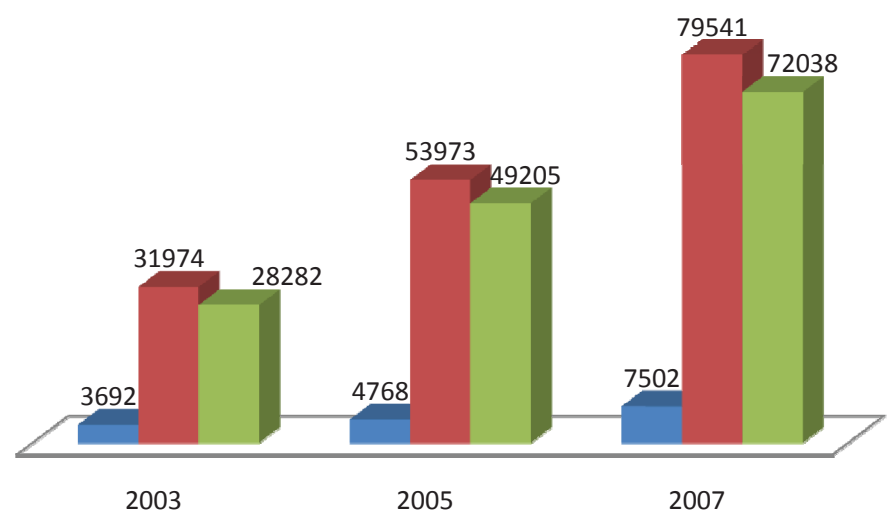

Source: Ministry of the Economy.

Graph 2

Mexican Trade Deficit with Asia and Oceania and Trade Surplus with the USA (US Millions)

Deficit with Asia and Oceania $\quad$ Surplus with USA

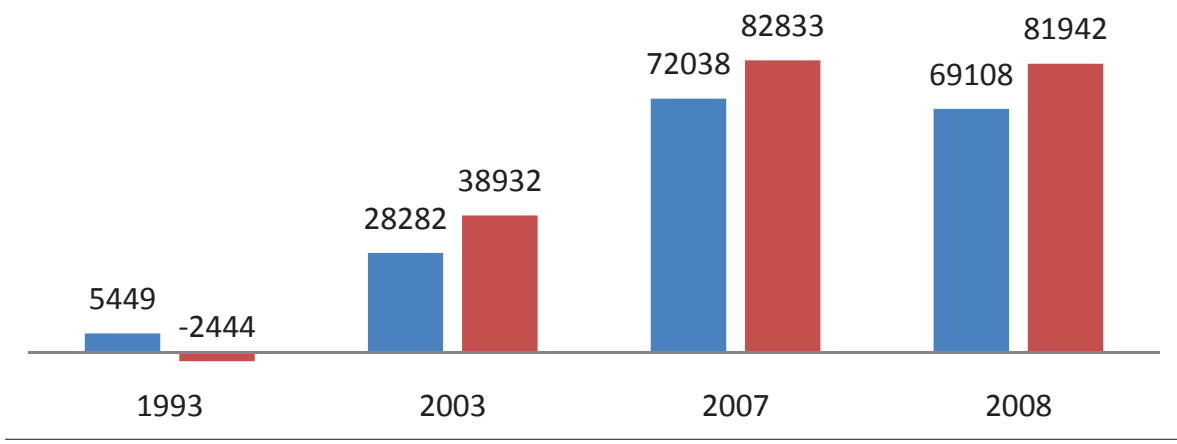

Source: Ministry of the Economy. 


\section{Graph 3}

Imports Composition 2007. Percentages

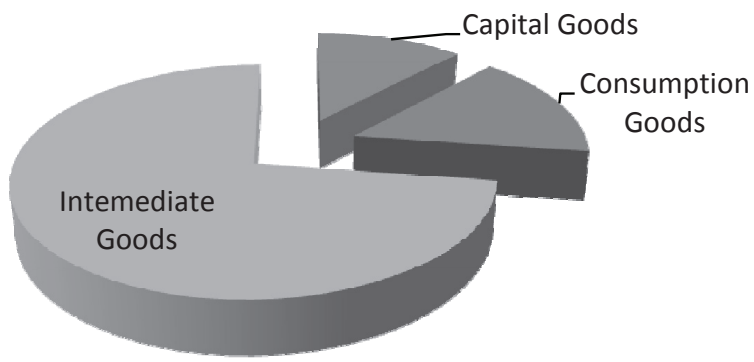

Source: Ministry of the Economy.

One important challenge for Mexico is to build a world class supporting industry, something which must happen in an environment of market openness. Domestic reforms in education, physical and human infrastructure, and enhanced links between industry and academic centers will be needed to reduce the import dependency from Asia and increase the competitiveness domestically produced final goods. Local Governments will be particularly interested in ensuring that something along the previous lines can happen.

\section{Mexico's trade opening momentum}

Mexico's trade opening momentum truly began since the aftermath of the debt crisis in 1982. Since then it has proceeded on two complementary tracks: unilaterally and through trade negotiations, the latter including the accession of Mexico to the General Agreement on Tariffs and Trade (GATT) in 1986 and the implementation of the NAFTA in 1994. For decades Mexico has been a member of the Latin American Integration Agreement (ALADI) and predecessor (ALALC), which meant partial tariff concessions among Latin American countries which still take place today. A relatively broader trade agreement with Chile took place in 1992.

After Mexico negotiated NAFTA, it began to negotiate a number of agreements which included countries in Central and South America (Guatemala, Honduras, El Salvador, Costa Rica, Nicaragua, Colombia, Venezuela, Bolivia, Uruguay and again Chile), the European Union, Israel, the European Free Trade Association (EFTA) and, more recently, Japan. In the pipeline there 
are pending negotiations with South Korea, Peru and Panama. Brazil has just been added to the list. An attempt to negotiate an agreement with Singapore took place towards the end of the 1990's, but efforts were abandoned in the face of fierce opposition by the industrial chambers in Mexico.

In recent days the Mexican Government has been exerting pressure on the private sector to begin the negotiation an FTA with Brazil, but the private sector has been reluctant to provide its consent to the Government once again, arguing about the lack of domestic reforms and the corresponding risk of opening up the economy to foreign competition. Moreover it is argued that Brazil has many non trade barriers and that so far Mexico has not been able to reap the benefits of its extensive array of FTAs.

While generally supportive of the first wave of Free Trade Agreement negotiations up until the early 2000s, the Mexican Private sector has grown increasingly opposed to further negotiations. Mexico's negotiating culture has customarily been to proceed to negotiate only with the consensus support of the Mexican private sector ${ }^{8}$, and this habit has become nowadays an impediment to proceed with negotiations in particular with Asian countries. An alternative approach used in other countries would be to proceed with the negotiations aiming at obtaining a satisfactory package to be submitted to the Mexican Senate for approval and ratification.

The consent of the industrial chambers has been necessary to begin negotiations. Moreover, no negotiation has been concluded without its consent. The private sector argues that many of the FTAs have not brought the benefits that were expected from them in terms of realizing export opportunities and have only opened the domestic market to increasing competition without having achieved domestic reforms thus harming the domestic industrial apparatus, and that any further trade opening either through FTAs or unilaterally should not proceed unless domestic "structural reforms" in sectors such as energy, taxation and labor are conducted, and a significant reduction in the cost of red tape takes place. ${ }^{9}$ The private sector argues that there is no real interest in aiming for non-traditional Asian markets.

8. COECE is the Coordinadora Empresarial de Comercio Exterior and the formal "room next door", in charge of providing advice and supervise the formal official negotiations. Consejo Coordinador Empresarial agglutinates all private sector chambers and is the top decision making body of the private sector.

9. See for example, Consejo Coordinador Empresarial, Agenda de Competitividad 2007. 
There is widespread fear that FTAs with Asian countries could expose the domestic industry to unfair economic competition due to the relative backwardness in domestic competitive conditions. FTAs with relatively more advanced economies such as the United States, the European Union or Japan have resulted in greater complementarities due to the greater differences in economic development and competitive advantages, while market opening with similar countries tends to be more difficult to accept by the Mexican industry.

While Mexico remains stuck on an endless and fruitless discussion about its pending domestic reforms, Asian countries have proceeded to negotiate agreements among themselves, which work against those Mexican firms willing to do business with Asian nations. Clearly East Asia is rapidly moving towards much greater free trade and integration. Unlike Chile, which has had a very active an aggressive negotiating agenda with Asia, Mexico's domestic troubles and inability to agree internally on anything are leaving Mexico out of these integrating efforts. The firms that are exporting or have a potential to do so to the Asian markets are feeling the effects of preferential market access being given to its rivals and are finding growing difficulties to export to these markets.

\section{An unwanted result of Mexican trade liberalization}

The numerous trade agreements and the corresponding preferential access Mexico must grant in each specific case, have given rise to a very complex customs administration system. This complexity in administration was significantly increased with the implementation of Article 303 of the NAFTA (duty drawback and duty deferral programs) in the early 2000s, which forbids the reduction or exemption of MFN tariffs for non NAFTA originating goods (i.e., imported mainly from Asia or elsewhere that are incorporated into goods exported to the United States or Canada).

Mexico should have proceeded to reduce MFN tariffs at least to the level of the United States to deal with the implementation of Article 303, and therefore avoid any loss in price competitiveness of Mexican manufacturers and exporters making intensive use of imports of parts and components from Asia. However, domestic firms were opposed to see MFN tariffs being reduced, while Japanese maquiladoras and other export oriented firms making intensive 
use of the older temporary importation regime were keen to maintain the tariff exemptions that had been allowed thus far to them.

The resulting arrangement by the interested parties mediated by the Government gave rise to the adoption of twenty four Sectorial Programs (called PROSECs), which establish for the same item differentiated tariff rates depending on its end use, aimed at reducing the negative impact on manufacturing operations making intensive use of non originating inputs.

After almost eight years of struggling with a heavy administrative burden, in order to eliminate the administrative complications and the resulting lack of transparency and perceived corruption in customs administration, in December of 2008 the Mexican Government, through a Presidential decree, announced the unilateral reduction or elimination of MFN tariffs in an ambitious and far reaching program, thereby substantially freeing trade on an MFN basis and abolishing preferential treatment on a quite substantial proportion of Mexican total trade.

The customs complexity resulting from Mexico's implementation of its tariff liberalization is practically impossible to be administered. The customs administration problems and corresponding unilateral tariff liberalization program are also being used as a lever to impose greater competition on the domestic industry.

Under the announced program, the simple average tariff will be reduced in five steps, from 10.4 percent in year 2008 to 4.3 percent by year 2013. The percentage of tariff lines with a zero tariff rate will be increased from 20 percent in year 2008 to 63 percent by year 2013. As a result, by year 2013 all PROSECs will be eliminated and a simplification of other preferential programs will also take place. No origin certification will be any longer necessary for a very large number of products. ${ }^{10}$

As expected, this program generated an angry reaction from the private sector, creating enormous tension with the Government. The Mexican Government has remained firm and has shown no intention to reverse the measure. Nonetheless the liberalization program decreed by the executive includes a commitment by the Government to conduct the needed reforms to strengthen Mexico's competitiveness. The customs administration problems

10. See Lorenza Martínez Trigueros, Facilitación Comercial, Foro sobre la Reforma Regulatoria, Secretaría de Economía y OCDE, January 2010. 
that market opening brought about by the negotiation of FTAs could be the trigger of the next wave of domestic reforms.

Facing the inevitable, the position of the Mexican private sector has been to demand from the executive the implementation of structural reforms in exchange of the tariff liberalization measures. Opposition parties in Congress, which bear great responsibility in the lack of implementation of the needed reforms, have threatened the executive branch with the removal of tariff reduction or elimination powers.

Mexico's aggressive Free Trade Agreements negotiating agenda up to the middle of the present decade created the conditions for a unilateral trade liberalization on and MFN basis. While aiming to create preferential treatment for its exports, particularly to the US market, the effects of article 303 and the resulting complexity in the administration of various PROSEC programs and trade regimes, together with the complexity to administrate numerous FTAs, forced the Mexican Government to unilaterally reduce tariffs while facing the growing competition of imports from Asia.

One important tool that the Government has to face market opening is the antidumping and safeguards provisions contained in its laws and trade agreements. As grater market opening proceeds, the Government will be under increased pressure to increase the number of antidumping investigations and cases to appease the private sector. During the present administration only a handful of investigations have resulted in the actual implementation of compensatory duties. One way to accommodate the pressure stemming from the private sector could be to allow more cases to end in the actual imposition of compensatory duties.

But more importantly, the inevitable competitive pressure coming from Asia and the announced trade opening of the Mexican economy means that Mexico must now necessarily conclude the pending structural reforms or else its domestic parts and components industry, which will experience the deepest reductions in tariffs, will have difficulties to survive. This could increase our import dependency from Asia. The moment is crucial to design and implement the right policies to strengthen the Mexican supporting industry under conditions of market openness.

In any case, market openness is only one important element of a number of factors that are considered essential to improve the competitiveness of any nation. In the next section a brief review of the huge pending domestic homework on competitiveness is provided. Given that Mexico will significantly 
open its economy against the rest of the world and that competition will be enhanced, something which is a desirable goal in itself, nonetheless Mexico needs to proceed fast in all fronts to ensure that the appropriate reforms and policies are implemented domestically in areas such as competition policy, reduction of regulatory burdens, human capacity building and physical infrastructure.

The discussion now includes market opening and domestic reforms as part of the same package. Market opening on an MFN basis now is a must in the Mexican economy and so is domestic reform. The key problem to advance the domestic reform agenda is the vested interest groups (including those from the private sector) which have become entrenched and opposed to any initiative that menaces to reduce the rents obtained from the status quo.

\section{Mexico's relative competitiveness}

In what follows, a brief comparison is made of various competitiveness factors across a sample of countries, including a number of important members of APEC. The competitiveness factors are called pillars of competitiveness. In the last few years Mexico dropped from position number 52 to position number 60 in the Global Competitiveness index (GCI) of the World Economic Forum (WEF). The main factors or pillars that determine the competitiveness of a nation according to the GCI are shown in chart 1.

Chart 1

Key Factors Considered by the Global Competitiveness Index of the World Economic Forum
1. Institutions
2. Infrastructure
3. Macroeconomic stability
4. Health and primary education
5. Higher education and training
6. Goods market efficiency
7. Labor market efficiency
8. Financial markets sophistication
9. Technological preparedness
10. Market size
11. Business sophistication
12. Innovation 
According to the 2009-2010 figures of the WEF (see the Annex to this Article), Mexico ranks above its own GCI ranking (place number 60) only in the following two pillars: Macroeconomic stability (28) and Market size (11). In all other items, Mexico falls below: Institutions (98), Infrastructure (69), health and primary education (65), higher education (74), goods market efficiency (90), labor market efficiency (115), financial markets sophistication (73), business sophistication (62) and innovation (78). Mexico ranks worst in the following (say above 70): institutions, goods market efficiency, labor market efficiency, and innovation. Regarding APEC members in the sample of countries chosen, only the Philippines, Vietnam, and Russia seem to rank consistently below Mexico.

Another interesting indicator of Mexico's relative performance in competitiveness is the evolution of the relative market share in the US market. ${ }^{11}$ China clearly has greatly improved its market share in the US market in the recent years. The table below shows how Mexico has consistently diminished its participation in the importation bill of the US, while China has consistently increased hers. This is most dramatically felt in sectors such as computer and telecom equipment, apparel and clothing. In the sample of products in the table, only auto-parts and electrical machinery have increased their market share. Furniture has resisted a major drop in its market share.

Table 4

Mexico faces China's competition

\begin{tabular}{|c|c|c|c|c|c|c|c|}
\hline \multirow[b]{2}{*}{$\begin{array}{c}\text { SITC } \\
\text { category }\end{array}$} & \multirow{2}{*}{\multicolumn{2}{|c|}{ Product }} & \multicolumn{2}{|c|}{2000} & \multicolumn{2}{|c|}{2007} & \multirow[b]{2}{*}{$\begin{array}{c}\text { Change in } \\
\text { Market Share } \\
2000-2007 \\
\end{array}$} \\
\hline & & & $\begin{array}{c}\text { Value } \\
\text { (billions) }\end{array}$ & $\begin{array}{c}\text { Share of } \\
\text { US market }\end{array}$ & $\begin{array}{c}\text { Value } \\
\text { (billions) }\end{array}$ & $\begin{array}{l}\text { Share of } \\
\text { US market }\end{array}$ & \\
\hline \multirow{3}{*}{752} & \multirow{3}{*}{$\begin{array}{c}\text { Automatic Data } \\
\text { Processing } \\
\text { Machines and Units }\end{array}$} & Mexico & 6.4 & 11.5 & 5.6 & 9.6 & \multirow{3}{*}{$\begin{array}{l}-1.9 \\
38.0\end{array}$} \\
\hline & & China & 6.3 & 11.3 & 28.6 & 49.3 & \\
\hline & & US Total & 55.9 & & 57.9 & & \\
\hline \multirow{3}{*}{764} & \multirow{3}{*}{$\begin{array}{c}\text { Telecommunications } \\
\text { Equipments and } \\
\text { Parts }\end{array}$} & Mexico & 9.1 & 20.6 & 10.8 & 13.6 & \multirow{3}{*}{$\begin{array}{l}-7.0 \\
26.9\end{array}$} \\
\hline & & China & 4.6 & 10.3 & 29.6 & 37.3 & \\
\hline & & US Total & 44.3 & & 79.5 & & \\
\hline \multirow{3}{*}{778} & \multirow{3}{*}{$\begin{array}{c}\text { Electrical Machinery } \\
\text { and Apparatus }\end{array}$} & Mexico & 3.1 & 18.3 & 5.0 & 21.8 & \multirow{3}{*}{$\begin{array}{r}3.5 \\
14.7\end{array}$} \\
\hline & & China & 2.0 & 11.9 & 6.1 & 26.6 & \\
\hline & & US Total & 17.1 & & 23.1 & & \\
\hline \multirow{3}{*}{784} & \multirow{3}{*}{$\begin{array}{l}\text { Auto Parts and } \\
\text { Accessories }\end{array}$} & Mexico & 4.6 & 16.3 & 10.2 & 22.2 & \multirow{3}{*}{$\begin{array}{l}5.8 \\
6.2\end{array}$} \\
\hline & & China & 0.4 & 1.5 & 3.6 & 7.8 & \\
\hline & & US Total & 28.4 & & 46.2 & & \\
\hline \multirow{3}{*}{821} & \multirow{3}{*}{ Furniture } & Mexico & 3.2 & 16.9 & 4.6 & 13.6 & \multirow{3}{*}{$\begin{array}{l}-3.3 \\
24.1\end{array}$} \\
\hline & & China & 4.5 & 23.6 & 16.2 & 47.7 & \\
\hline & & US Total & 18.9 & & 33.9 & & \\
\hline \multirow{3}{*}{84} & \multirow{3}{*}{$\begin{array}{l}\text { Articles of Apparel } \\
\text { and Cothing }\end{array}$} & Mexico & 8.7 & 13.6 & 4.7 & 5.8 & \multirow{3}{*}{$\begin{array}{l}-7.8 \\
20.2\end{array}$} \\
\hline & & China & 8.5 & 13.2 & 27.1 & 33.4 & \\
\hline & & US Total & 64.3 & & 81.2 & & \\
\hline
\end{tabular}

Source: US Department of Commerce (http/ldataweb.usitc.gov), Downloaded Feb 21, 2008

11. This table was obtained from the Economic Strategy Institute in Washington D.C. 
Another key indicator is the growth in GDP per capita, which is clearly correlated with increases in labor productivity ${ }^{12}$. In graph number 4 , when compared with other OECD partners, Mexico clearly has been simply unable to take off. GDP per capita growth has been practically absent in a long term perspective. The lesson learned is that in spite of NAFTA and macroeconomic stability (the two major achievements) Mexico has not been able to improve significantly its standards of living due to lagging competitiveness and lacking reform.

\section{Graph 4}

Income per capita growth

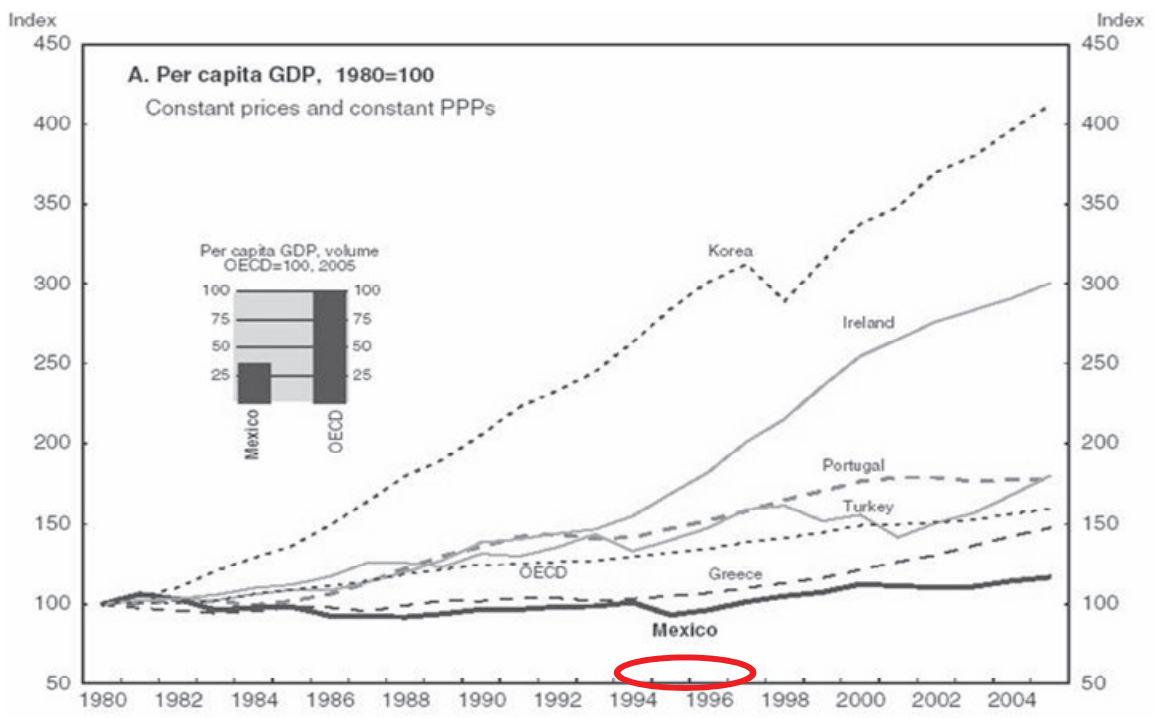

Source: OECD.

How can Mexico improve its standard of living? Given the present decision to unilaterally open up the Mexican economy, how can Mexico advance its reform agenda? Mexico's problems to move ahead on a reform agenda are mainly domestic and have to do with the difficulty to agree by the key political actors, including labor unions and the private sector. There might be two alternatives or a combination of both to break the present impasse.

12. This graph was also obtained from the Economic Strategy Institute in Washington DC. 
The first one is that, given the decision to open up the economy and expose it to greater international competition, all relevant economic actors get together and agree to implement the pending reforms in areas such as labor market flexibility, economic competition, regulatory reform, energy and others where the WEF indicates that improvement needs to be made. In this first case scenario the federal Government, states and municipalities, the private sector, the judiciary, both chambers of congress, the labor movement, academics and organized civil society would need to get together and decide on the needed reforms. To achieve this is tremendously complex and requires lots of leadership. Transparency in procedures must be a sine qua non of any attempt to move ahead with a reform that will indeed benefit society and not just particular groups of citizens.

The second scenario to assist Mexico achieve reform is to tie itself to an international agenda or agreement on structural reforms that will limit the power of the usual suspects or interest groups that have enormous power over political parties and impede the realization of reforms, such as monopolies and labor unions. This international agenda on structural reform could assist the Government to contain important constituencies and obtain greater degrees of freedom to pursue the needed reforms. Indeed, carefully framed international agreements are a means to assist domestic reformers to overcome resistance from those opposed to change.

Mexico renegotiated its external debt and began to implement macroeconomic stability in the late 1980s (with the stumbling episode of the Tequila Crisis in 1994), implemented the NAFTA and created a network of FTAs in the 1990s and up to the mid 2000s, but failed to create the suitable institutions and regulatory frameworks that had to accompany those achievements, including the development of strong and truly independent commissions dealing with competition, telecommunications, energy and regulatory improvement.

Mexico did not do its homework well in the recent past, and now that the preferential market access to the US market is significantly eroded and that it must unilaterally open it economy it must urgently implement its domestic reforms. Moreover, in the presence of growing pressure from a number of competitors, particularly from Asia, Mexico is trapped in a situation where its domestic actors are simply unable to agree on an agenda for the improvement of its competitive position. 


\section{Graph 5}

Global Competitiveness Index - WEF

$$
\text { — 2009-2010 - 2008-2009 }
$$

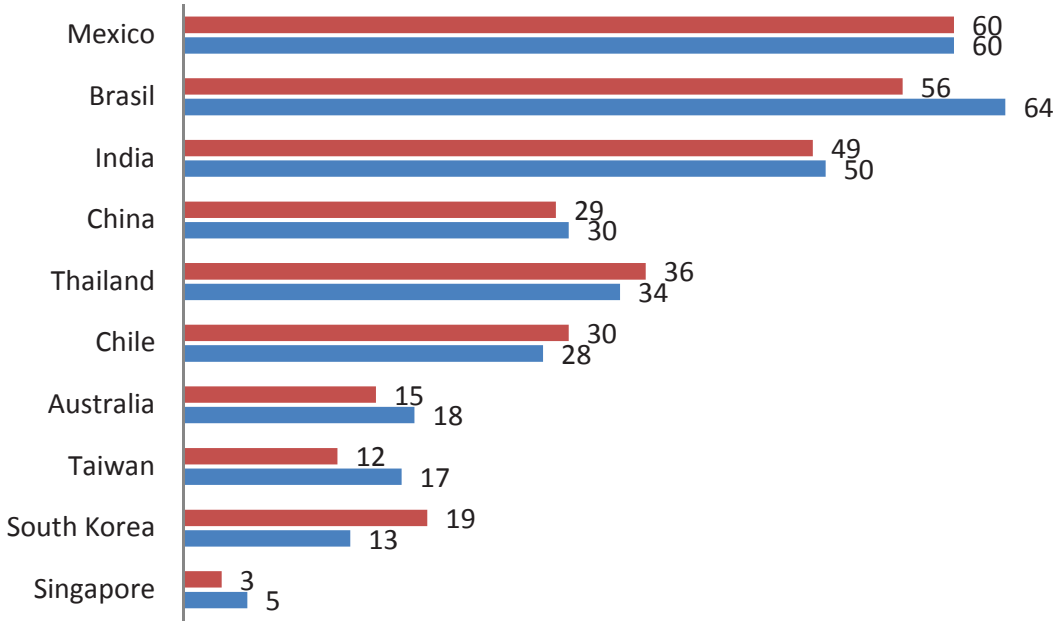

Source: World Economic Forum.

Mexico must clearly advance in the ladder of competitiveness to become an economy that is more intensive in knowledge, and that produces goods and services with higher quality and higher value added. Only in this manner will Mexico be able to be more successful in international markets and create better jobs. The negotiation of FTAs, including NAFTA, has been insufficient to initiate a process of convergence to the standards of living of our more advanced trading partners. Other forms of association have produced better results in this regard.

\section{APEC and its relevance for Mexico's present conundrums}

APEC is mainly characterized by the promotion of trade and investment liberalization and facilitation as well as economic and technical cooperation among its 21 member economies. APEC operates without requiring that its members contract legally binding obligations. It is an informal organiza- 
tion since it lacks a formal constitution. This characteristic is considered a handicap by its critics since there is no manner to guarantee the fulfillment of its political commitments other than by exercising peer pressure by the membership. Nonetheless, without binding commitments the region has impressively continued its movement towards greater market openness and greater integration.

APEC represents the most dynamic region in the world generating over 70 percent of global economic growth in the past decade, and its membership amounts to a total population of 2.6 billion, representing over 55 percent of world output and almost half of world trade. Moreover, for more than 15 years APEC has allowed the heads of state and Government in the region to convene once a year in an informal setting to discuss issues of central importance to the region, including trade and investment liberalization, economic reform and security related issues.

Trade between Mexico and APEC members represents close to 85 percent of its total trade. Six out of its nine main trading partners belong to APEC: United States, China, Japan, Canada, South Korea, and Chinese Taipei. Seventy percent of FDI received by Mexico originates in the APEC region and Mexico has FTAs with four APEC members: Canada, United States, Chile and Japan. Trade negotiations are on the pipeline with Peru and South Korea. Other countries have expressed their willingness to negotiate FTAs with Mexico such as Singapore, Australia and New Zealand. Moreover, Mexico has negotiated Bilateral Investment Treaties with South Korea, Australia and China, and is negotiating such agreements with Singapore, Indonesia, Malaysia, and Russia.

The high dependence on imports from Asia, not only of final consumption goods but mainly on imports of intermediate and capital goods, as well as the closeness of its relationship with the United States, still the largest single market of the world, are sufficient ingredients for Mexico to have a clear Asia Pacific vocation. Mexico is indeed an Asia Pacific country.

Ideally Mexico, like Chile, while aiming to liberalize a large portion of its trade unilaterally, should aim to negotiate agreements with most if not all of $\mathrm{APEC}$ members in order to obtain reciprocity. However, due to the reluctance of its private sector to engage in trade negotiations with Asian countries, Mexico is unfortunately lagging behind the rest of the initiatives that are ongoing in the region. The private sector should reconsider its position while pressing for domestic reforms. Instead of aiming to diversify trade and deepen 
Table 4

Mexican Imports by Country of Origin

Main Suppliers (Percentages)

\begin{tabular}{lrrr}
\hline Country & 1993 & 2007 & Jan-Nov 2009 \\
\hline USA & 69.29 & 49.63 & 47.44 \\
China & 0.59 & 10.52 & 13.86 \\
Japan & 6.01 & 5.78 & 4.88 \\
South Korea & 1.42 & 4.47 & 4.7 \\
Germany & 4.36 & 3.78 & 4.18 \\
Canada & 1.8 & 2.82 & 3.1 \\
Taipei & 1.1 & 2.08 & 1.95 \\
Brasil & 1.84 & 1.97 & 1.5 \\
Italy & 1.28 & 1.96 & 1.35 \\
Spain & 1.77 & 1.35 & 1.28 \\
\hline
\end{tabular}

Source: Ministry of the Economy.

Table 5

Mexican Export Destinations (percentages)

\begin{tabular}{lrrrr}
\hline Country & 1993 & 2007 & 2008 & Jan-Nov 2009 \\
\hline USA & 82.67 & 82.12 & 80.2 & 80.59 \\
Canada & 3.027 & 2.39 & 2.4 & 3.63 \\
Germany & 0.83 & 1.51 & 1.7 & 1.37 \\
Spain & 1.771 & 1.32 & 1.5 & 1.05 \\
Colombia & 0.461 & 1.08 & 1 & 1.1 \\
Venezuela & 0.44 & 0.86 & 0.8 & 0.64 \\
China & 0.086 & 0.7 & 0.7 & 1 \\
Japan & 1.324 & 0.7 & 0.7 & 0.7 \\
Brasil & 0.564 & 0.74 & 1.2 & 1.1 \\
Netherlands & 0.373 & 0.58 & 0.7 & 0.7 \\
\hline
\end{tabular}

Source: Ministry of the Economy

its trade and investment relationship with Asia Pacific, Mexico has been overly cautious and incapable of using APEC as a means of approaching strategic partners, fearsome of the competition that could come from Asia.

In recent times, APEC has moved from a main focus on trade and investment liberalization and facilitation and economic and technical cooperation, 
to an agenda also focusing on domestic "structural" reforms, such as the Leaders Agenda to Implement Structural Reform (LAISR agenda), aiming to strengthen economic competition and regulatory reform. In this regard, APEC can contribute to reinforce the Mexican domestic reform agenda in a similar manner as the OECD does, by providing political support and technical assistance through best practices of its members. It reinforces the domestic unilateral trade and investment liberalization agenda and also contributes to reinforce the domestic structural reform agenda.

In 2004, the LAISR Structural Reform agenda was established. The objective of LAISR is to increase the standards of living in a sustainable manner and attain the economic potential of the region by means of increasing economic efficiency and competitiveness. LAISR aims to addresses structural reform, economic legal infrastructure, competition policy, corporate governance and public sector management among other issues. It seeks to promote structural reform, promote the understanding of the benefits of structural reform, provide capacity building, strengthen cooperation with other international organizations such as the OECD and the World Bank, accelerate domestic reform efforts, and enhance transparency with a view to eliminate corruption. More recently, in 2008 Australia organized the first Ministerial Meeting on Structural Reform.

The 2010 APEC Economic Leaders Meeting Declaration speaks about strengthening long term potential output growth and narrowing the development gap. Leaders have agreed to reenergize APECs work on structural reform building on the LAISR agenda. Mexico should become a leader in this area and use APEC to exercise pressure on its domestic constituencies.

Although traditional economic cooperation programs such as the exchange of experts and capacity building seminars have not represented a major element of Mexico's participation in APEC, there is ample room to take greater advantage of APECs drive to liberalize trade and conduct required domestic reforms to reduce the gap among levels of development.

In particular, in order to be able to capitalize its unilateral trade liberalization efforts, Mexico should endorse the negotiation of a Free Trade Agreement of the Asia Pacific (FTAAP) region and in the meantime become engaged in the Transpacific Strategic Economic Partnership. In 2009 APEC Leaders agreed to continue to explore building blocks towards a possible FTAAP in the future. 
At its present crossroad, Mexico can clearly benefit from APEC's agenda by reaffirming its unilateral trade opening initiative and pursuing its domestic structural reforms. However, at the present stage, the most APEC can do to stimulate the needed domestic reforms and market opening is to provide political support and valuable technical advice and experience by its members. Mexico can also use APEC as a window to learn more about what its APEC partners are doing to enhance their competitiveness.

\section{Conclusions and next steps}

Mexico desperately needs to enhance its competitiveness or else will keep lagging behind, particularly in standards of living. The negotiation of NAFTA Article 303 implied that Mexico had no choice in the long term but to reduce its MFN tariffs at least to the level of those of the United States, its main trading partner. Instead, under the pressure of its private sector, it decided to implement PROSECs, which represent a set of end use provision programs which are very complex to administer. Together with the proliferation of FTAs negotiated by Mexico, it has made of the customs administration a real conundrum where lack of transparency prevails.

Most importantly, the present Government has taken the bold and strategic decision to unilaterally dismantle the programs and move to free trade in about two thirds of its tariff lines. The trade and investment liberalization goals of APEC clearly assist Mexico in promoting and supporting its unilateral liberalization policies. Moreover, given its unilaterally proclaimed and decreed trade liberalization, Mexico must push hard for the negotiation of a possible FTAAP.

On the other hand, Mexico also urgently needs to pursue domestic reforms to catch up in competitiveness or at least to avoid continue dropping in the global rankings, which are associated with investment sentiment. In this regard, APEC has a structural reform agenda which clearly coincides with Mexico's aims. Lack of competition, particularly in the provision of basic inputs such as telecommunication, transportation, energy and financial services, gives rise to an inefficient use of resources and diminishes the competitiveness of the rest of productive activities. Domestic reforms are urgently needed.

In other words, to stimulate the productivity and innovation of firms, Mexico needs to enhance market competition. The regulatory framework and 
investment climate must be improved to increase its competitiveness. This is needed to boost productivity and growth. Mexican markets suffer from inadequate competition conditions, with overregulated and closed economic sectors. Only by addressing these challenges can Mexico begin to fully develop important competitive advantages.

Mexico is at a decisive moment. Mexico is lagging behind in competitiveness and needed reforms are still lacking. Other countries continue advancing while Mexico falls behind. The competitive pressure stemming from Asia increases, particularly as Mexico opens its economy, and this will be a factor to increase pressure on the political apparatus which seems incapable of providing the needed reforms. The promotion of greater competition to improve productivity and innovation, the promotion of better regulation to reduce the bureaucratic cost of doing business, the improvement of human and physical infrastructure, and the enhancement of the rule of law and efficiency of our Government are among the pending issues that Mexico requires to improve.

In recent times the Mexican Government together with the OECD embarked on a revision of policies, laws and regulations which are expected to bring important results. One important result already has been the creation of an on-line site for the creation of new enterprises, which reduces significantly time, steps and money needed to establish new enterprises. Although a relatively small step in comparison with the enormous task ahead, it is an excellent beginning that points in the right direction.

In the process of regulatory reform it is necessary to find the spaces for a fruitful dialogue among political parties, the executive, legislative, the private sector, the states, municipalities, labor unions, academics and civil society. Leadership and vision will be needed to conduct this reform process. APEC, together with other international organizations like the OECD, can assist Mexico in creating the right atmosphere to promote the needed change.

International experience shows that those countries that have promoted competition and diminished regulatory burdens have been capable to enhance economic growth, and have created more and better jobs, enhancing productivity, innovation and thus competitiveness. The active commitment and participation of all actors involved in the process are fundamental to achieve the needed substantive agreements and ensure success. mig 


\section{Bibliography}

Barfield, Claude and Phillip I Levy, "The Trans-Pacific Partnership and US Leadership in Asia", VOX Research based policy analysis, http://www. voxeu.org

Consejo Coordinador Empresarial, Agenda de Competitividad 2007, México 2007.

Diario Oficial de la Federación, Decreto por el que se modifica la tarifa de la Ley de los Impuestos Generales de Importación y Exportación, México, 24 de diciembre de 2008

Diario Oficial de la Federación, Decreto por el que se establecen diversos Programas de Promoción Sectorial, México, enero de 2002

Inteligencia Comercial IQOM, Continúan países de Asia Proceso de Integración Comercial: México se mantiene al margen. Enero de 2010. www.iqom.com. $\mathrm{mx}$

Inteligencia Comercial IQOM, Implementa economía la reducción arancelaria más ambiciosa de los últimos 20 años: análisis de sus principales elementos, Enero de 2009. www.iqom.com.mx

Lorenza Martínez Trigueros, Facilitación Comercial, Foro sobre la Reforma Regulatoria, Secretaría de Economía y OCDE, January 2010.

World Economic Forum, Competitiveness Report, various issues. www.weforum.org 
José Gerardo Traslosheros Hernández

\section{ANNEX (for the following charts data is taken from the WEF Competitiveness Report, 2009 - 2010)}

\begin{tabular}{|l|c|c|}
\hline \multicolumn{2}{|c|}{ MACROECONOMIC STABILITY } \\
\hline COUNTRY / ECONOMY & RANK & SCORE \\
\hline Luxembourg & 6 & 5.95 \\
\hline China & 8 & 5.93 \\
\hline Korea, Rep. & 11 & 5.80 \\
\hline Finland & 12 & 5.78 \\
\hline Denmark & 14 & 5.71 \\
\hline Sweden & 15 & 5.70 \\
\hline Switzerland & 17 & 5.63 \\
\hline Australia & 18 & 5.56 \\
\hline Chile & 19 & 5.48 \\
\hline Taiwan, China & 25 & 5.34 \\
\hline Mexico & 28 & 5.29 \\
\hline Germany & 30 & 5.28 \\
\hline New Zealand & 33 & 5.24 \\
\hline Singapore & 35 & 5.24 \\
\hline Russian Federation & 36 & 5.24 \\
\hline Malaysia & 42 & 5.00 \\
\hline Indonesia & 52 & 4.82 \\
\hline Bolivia & 60 & 4.70 \\
\hline I I I & 1 & 1 \\
\hline
\end{tabular}

\begin{tabular}{|l|c|c|}
\hline El Salvador & 61 & 4.68 \\
\hline Peru & 63 & 4.66 \\
\hline Namibia & 66 & 4.62 \\
\hline South Africa & 68 & 4.62 \\
\hline Colombia & 72 & 4.59 \\
\hline Poland & 74 & 4.56 \\
\hline Philippines & 76 & 4.54 \\
\hline Portugal & 79 & 4.52 \\
\hline Honduras & 85 & 4.44 \\
\hline Guatemala & 88 & 4.43 \\
\hline Venezuela & 91 & 4.38 \\
\hline United States & 93 & 4.31 \\
\hline India & 96 & 4.23 \\
\hline Japan & 97 & 4.22 \\
\hline Costa Rica & 101 & 4.11 \\
\hline Greece & 103 & 4.02 \\
\hline Ukraine & 106 & 3.96 \\
\hline Brazil & 109 & 3.93 \\
\hline Vietnam & 112 & 3.86 \\
\hline Egypt & 120 & 3.46 \\
\hline & 1 & \\
\hline & $I$ & \\
\hline
\end{tabular}

\begin{tabular}{|l|c|c|}
\hline \multicolumn{3}{|c|}{ INFRAESTRUCTURE } \\
\hline COUNTRY / ECONOMY & RANK & SCORE \\
\hline Germany & 1 & 6.59 \\
\hline Singapore & 4 & 6.35 \\
\hline Switzerland & 5 & 6.35 \\
\hline United States & 8 & 5.92 \\
\hline Finland & 10 & 5.87 \\
\hline Denmark & 12 & 5.83 \\
\hline Japan & 13 & 5.83 \\
\hline Sweden & 14 & 5.82 \\
\hline Taiwan, China & 16 & 5.60 \\
\hline Korea, Rep. & 17 & 5.60 \\
\hline Luxembourg & 19 & 5.56 \\
\hline Portugal & 23 & 5.23 \\
\hline Australia & 25 & 5.19 \\
\hline Malaysia & 26 & 5.05 \\
\hline Chile & 30 & 4.93 \\
\hline Namibia & 32 & 4.77 \\
\hline New Zealand & 35 & 4.64 \\
\hline South Africa & 45 & 4.33 \\
\hline I I I & & 1 \\
\hline
\end{tabular}

\begin{tabular}{|l|c|c|}
\hline China & 46 & 4.31 \\
\hline Greece & 47 & 4.31 \\
\hline El Salvador & 51 & 4.20 \\
\hline Egypt & 55 & 4.07 \\
\hline Guatemala & 68 & 3.78 \\
\hline Mexico & 69 & 3.69 \\
\hline Russian Federation & 71 & 3.62 \\
\hline Brazil & 74 & 3.50 \\
\hline India & 76 & 3.47 \\
\hline Honduras & 77 & 3.39 \\
\hline Ukraine & 78 & 3.39 \\
\hline Costa Rica & 82 & 3.24 \\
\hline Colombia & 83 & 3.20 \\
\hline Indonesia & 84 & 3.20 \\
\hline Vietnam & 94 & 3.00 \\
\hline Peru & 97 & 2.91 \\
\hline Philippines & 98 & 2.91 \\
\hline Poland & 103 & 2.88 \\
\hline Venezuela & 106 & 2.80 \\
\hline Bolivia & 122 & 2.47 \\
\hline \multicolumn{1}{|}{ I I } & \\
\hline & & \\
\hline
\end{tabular}




\begin{tabular}{|l|c|c|}
\hline \multicolumn{1}{|c|}{ HEATLTH AND PRIMARY EDUCATION } \\
\hline COUNTRY / ECONOMY & RANK & SCORE \\
\hline Finland & 1 & 6.46 \\
\hline New Zealand & 4 & 6.43 \\
\hline Denmark & 6 & 6.31 \\
\hline Sweden & 12 & 6.22 \\
\hline Singapore & 13 & 6.22 \\
\hline Taiwan, China & 15 & 6.20 \\
\hline Australia & 16 & 6.18 \\
\hline Japan & 19 & 6.13 \\
\hline Switzerland & 21 & 6.10 \\
\hline Germany & 24 & 6.01 \\
\hline Luxembourg & 25 & 6.01 \\
\hline Korea, Rep. & 27 & 5.99 \\
\hline Costa Rica & 29 & 5.97 \\
\hline Portugal & 31 & 5.95 \\
\hline Malaysia & 34 & 5.90 \\
\hline Poland & 35 & 5.88 \\
\hline United States & 36 & 5.88 \\
\hline Greece & 41 & 5.81 \\
\hline
\end{tabular}

\begin{tabular}{|l|c|c|}
\multicolumn{1}{|c|}{} \\
\hline China & 45 & 5.72 \\
\hline Russian Federation & 51 & 5.65 \\
\hline Mexico & 65 & 5.48 \\
\hline Ukraine & 68 & 5.41 \\
\hline Chile & 69 & 5.38 \\
\hline Colombia & 72 & 5.34 \\
\hline Vietnam & 76 & 5.28 \\
\hline Brazil & 79 & 5.24 \\
\hline Venezuela & 81 & 5.22 \\
\hline Indonesia & 82 & 5.20 \\
\hline Egypt & 84 & 5.20 \\
\hline Honduras & 85 & 5.18 \\
\hline El Salvador & 86 & 5.17 \\
\hline Peru & 91 & 5.14 \\
\hline Philippines & 93 & 5.07 \\
\hline Bolivia & 94 & 5.05 \\
\hline Guatemala & 95 & 5.04 \\
\hline India & 101 & 4.82 \\
\hline Namibia & 109 & 4.28 \\
\hline South Africa & 125 & 3.60 \\
\hline I & & \\
\hline
\end{tabular}

\begin{tabular}{|l|c|c|}
\hline \multicolumn{3}{c}{$/$} \\
\hline \multicolumn{1}{c}{ HIGHER EDUCATION } \\
\hline COUNTRY I ECONOMY & RANK & SCORE \\
\hline Finland & 1 & 5.97 \\
\hline Denmark & 2 & 5.90 \\
\hline Sweden & 3 & 5.76 \\
\hline Singapore & 5 & 5.62 \\
\hline Switzerland & 6 & 5.60 \\
\hline United States & 7 & 5.57 \\
\hline New Zealand & 11 & 5.49 \\
\hline Taiwan, China & 13 & 5.43 \\
\hline Australia & 14 & 5.33 \\
\hline Korea, Rep. & 16 & 5.24 \\
\hline Germany & 22 & 5.07 \\
\hline Japan & 23 & 5.06 \\
\hline Poland & 27 & 4.82 \\
\hline Portugal & 38 & 4.58 \\
\hline Luxembourg & 39 & 4.51 \\
\hline Malaysia & 41 & 4.49 \\
\hline Greece & 43 & 4.43 \\
\hline Costa Rica & 44 & 4.42 \\
\hline \ $\backslash$ & & 1 \\
\hline
\end{tabular}

\begin{tabular}{|l|c|c|}
\hline \multicolumn{1}{|c|}{$\backslash$ Chile } & \multicolumn{1}{c}{$\backslash$} \\
\hline Ukraine & 46 & 4.40 \\
\hline Russian Federation & 51 & 4.38 \\
\hline Brazil & 58 & 4.14 \\
\hline China & 61 & 4.09 \\
\hline South Africa & 65 & 4.00 \\
\hline India & 66 & 3.96 \\
\hline Philippines & 68 & 3.92 \\
\hline Indonesia & 69 & 3.91 \\
\hline Colombia & 71 & 3.89 \\
\hline Mexico & 74 & 3.86 \\
\hline Peru & 81 & 3.75 \\
\hline Venezuela & 83 & 3.71 \\
\hline Egypt & 88 & 3.62 \\
\hline Vietnam & 92 & 3.54 \\
\hline Bolivia & 93 & 3.51 \\
\hline El Salvador & 95 & 3.48 \\
\hline Guatemala & 101 & 3.34 \\
\hline Honduras & 106 & 3.22 \\
\hline Namibia & 110 & 3.18 \\
\hline / / & $/$ \\
\hline
\end{tabular}


José Gerardo Traslosheros Hernández

\begin{tabular}{|l|c|c|}
\hline \multicolumn{2}{|c|}{ GOODS MARKET EFFICIENCY } \\
\hline COUNTRY I ECONOMY & RANK & SCORE \\
\hline Singapore & 1 & 5.77 \\
\hline Luxembourg & 3 & 5.38 \\
\hline Sweden & 4 & 5.27 \\
\hline Switzerland & 5 & 5.24 \\
\hline Denmark & 7 & 5.21 \\
\hline New Zealand & 8 & 5.20 \\
\hline Australia & 9 & 5.20 \\
\hline United States & 12 & 5.13 \\
\hline Taiwan, China & 14 & 5.10 \\
\hline Japan & 17 & 5.06 \\
\hline Germany & 18 & 5.01 \\
\hline Finland & 19 & 4.98 \\
\hline Chile & 26 & 4.83 \\
\hline Malaysia & 30 & 4.77 \\
\hline South Africa & 35 & 4.65 \\
\hline Korea, Rep. & 36 & 4.64 \\
\hline Indonesia & 41 & 4.49 \\
\hline China & 42 & 4.47 \\
\hline$\backslash$ & & 1 \\
\hline \multicolumn{1}{|c|}{$\backslash 1$} & & \\
\hline
\end{tabular}

\begin{tabular}{|l|c|c|}
\hline \multicolumn{1}{|c|}{ Costa Rica } & 47 & 4.42 \\
\hline India & 48 & 4.42 \\
\hline El Salvador & 50 & 4.40 \\
\hline Portugal & 51 & 4.39 \\
\hline Guatemala & 52 & 4.34 \\
\hline Poland & 53 & 4.34 \\
\hline Peru & 66 & 4.21 \\
\hline Vietnam & 67 & 4.20 \\
\hline Greece & 75 & 4.09 \\
\hline Namibia & 77 & 4.07 \\
\hline Honduras & 80 & 4.03 \\
\hline Egypt & 87 & 3.99 \\
\hline Colombia & 88 & 3.98 \\
\hline Mexico & 90 & 3.97 \\
\hline Philippines & 95 & 3.92 \\
\hline Brazil & 99 & 3.87 \\
\hline Russian Federation & 108 & 3.75 \\
\hline Ukraine & 109 & 3.74 \\
\hline Bolivia & 131 & 3.03 \\
\hline Venezuela & 132 & 2.88 \\
\hline$/$ & $/$ & $/$ \\
\hline & & \\
\hline
\end{tabular}

\begin{tabular}{|l|c|c|}
\hline \multicolumn{2}{|c|}{ LABOR MARKET EFFICIENCY } \\
\hline COUNTRY /ECONOMY & RANK & SCORE \\
\hline Singapore & 1 & 5.91 \\
\hline Switzerland & 2 & 5.78 \\
\hline United States & 3 & 5.76 \\
\hline Denmark & 5 & 5.53 \\
\hline Australia & 9 & 5.20 \\
\hline New Zealand & 11 & 5.12 \\
\hline Japan & 12 & 5.10 \\
\hline Sweden & 19 & 4.91 \\
\hline Finland & 23 & 4.85 \\
\hline Taiwan, China & 24 & 4.85 \\
\hline Malaysia & 31 & 4.74 \\
\hline China & 32 & 4.74 \\
\hline Costa Rica & 36 & 4.71 \\
\hline Vietnam & 38 & 4.70 \\
\hline Chile & 41 & 4.69 \\
\hline Luxembourg & 42 & 4.67 \\
\hline Russian Federation & 43 & 4.67 \\
\hline Ukraine & 49 & 4.57 \\
\hline I $~ \$ & 1 & 1 \\
\hline
\end{tabular}

\begin{tabular}{|c|c|c|}
\hline Poland & 50 & 4.54 \\
\hline Namibia & 57 & 4.48 \\
\hline EI Salvador & 68 & 4.36 \\
\hline Germany & 70 & 4.33 \\
\hline Indonesia & 75 & 4.30 \\
\hline Peru & 77 & 4.30 \\
\hline Colombia & 78 & 4.29 \\
\hline Brazil & 80 & 4.27 \\
\hline India & 83 & 4.23 \\
\hline Korea, Rep. & 84 & 4.22 \\
\hline Guatemala & 88 & 4.17 \\
\hline South Africa & 90 & 4.15 \\
\hline Portugal & 103 & 4.04 \\
\hline Philippines & 113 & 3.89 \\
\hline Mexico & 115 & 3.82 \\
\hline Greece & 116 & 3.80 \\
\hline Honduras & 121 & 3.65 \\
\hline Egypt & 126 & 3.46 \\
\hline Bolivia & 131 & 3.15 \\
\hline Venezuela & 133 & 2.91 \\
\hline
\end{tabular}


Mexico in Asia Pacific: Lagging Competitiveness and Lacking Reform

\begin{tabular}{|l|c|c|}
\hline \multicolumn{2}{|c|}{ TECHONOLOGICAL READINESS } \\
\hline COUNTRY / ECONOMY & RANK & SCORE \\
\hline Sweden & 1 & 6.15 \\
\hline Switzerland & 3 & 6.01 \\
\hline Denmark & 4 & 5.92 \\
\hline Luxembourg & 5 & 5.91 \\
\hline Singapore & 6 & 5.90 \\
\hline Finland & 10 & 5.64 \\
\hline Germany & 12 & 5.63 \\
\hline United States & 13 & 5.61 \\
\hline Korea, Rep. & 15 & 5.50 \\
\hline Taiwan, China & 18 & 5.43 \\
\hline Australia & 20 & 5.39 \\
\hline New Zealand & 23 & 5.24 \\
\hline Japan & 25 & 5.23 \\
\hline Portugal & 31 & 4.73 \\
\hline Malaysia & 37 & 4.51 \\
\hline Chile & 42 & 4.28 \\
\hline Brazil & 46 & 4.06 \\
\hline Poland & 48 & 3.97 \\
\hline$\backslash$ & & 1 \\
\hline
\end{tabular}

\begin{tabular}{|l|c|c|}
\hline Greece & 53 & 3.86 \\
\hline Costa Rica & 62 & 3.72 \\
\hline South Africa & 65 & 3.69 \\
\hline Colombia & 66 & 3.57 \\
\hline Guatemala & 70 & 3.53 \\
\hline Mexico & 71 & 3.53 \\
\hline Vietnam & 73 & 3.45 \\
\hline Russian Federation & 74 & 3.45 \\
\hline Peru & 77 & 3.39 \\
\hline China & 79 & 3.38 \\
\hline Ukraine & 80 & 3.37 \\
\hline El Salvador & 81 & 3.36 \\
\hline Egypt & 82 & 3.35 \\
\hline India & 83 & 3.33 \\
\hline Philippines & 84 & 3.32 \\
\hline Namibia & 86 & 3.26 \\
\hline Indonesia & 88 & 3.20 \\
\hline Venezuela & 91 & 3.16 \\
\hline Honduras & 93 & 3.13 \\
\hline Bolivia & 128 & 2.34 \\
\hline / / / & \\
\hline
\end{tabular}

\begin{tabular}{|l|c|c|}
\hline \multicolumn{1}{|c|}{ FINANCIAL MARKET SOPHISTICATION } \\
\hline COUNTRY / ECONOMY & RANK & SCORE \\
\hline Singapore & 2 & 5.91 \\
\hline New Zealand & 3 & 5.69 \\
\hline Australia & 4 & 5.51 \\
\hline South Africa & 5 & 5.43 \\
\hline Malaysia & 6 & 5.38 \\
\hline Finland & 7 & 5.33 \\
\hline Denmark & 8 & 5.31 \\
\hline Luxembourg & 9 & 5.31 \\
\hline Sweden & 12 & 5.17 \\
\hline Switzerland & 14 & 5.15 \\
\hline India & 16 & 5.10 \\
\hline United States & 20 & 4.96 \\
\hline Namibia & 31 & 4.74 \\
\hline Chile & 32 & 4.72 \\
\hline Germany & 36 & 4.68 \\
\hline Peru & 39 & 4.66 \\
\hline Japan & 40 & 4.65 \\
\hline Poland & 44 & 4.61 \\
\hline I & & 1 \\
\hline
\end{tabular}

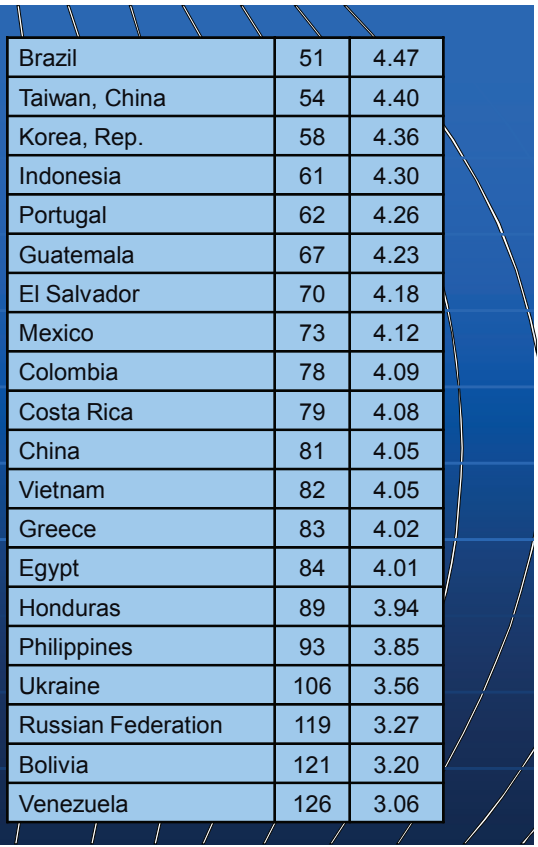


José Gerardo Traslosheros Hernández

\begin{tabular}{|l|c|c|}
\hline \multicolumn{3}{|c|}{ MARKET SIZE } \\
\hline COUNTRY / ECONOMY & RANK & SCORE \\
\hline United States & 1 & 6.93 \\
\hline China & 2 & 6.63 \\
\hline Japan & 3 & 6.17 \\
\hline India & 4 & 6.07 \\
\hline Germany & 5 & 6.02 \\
\hline Russian Federation & 7 & 5.78 \\
\hline Brazil & 10 & 5.63 \\
\hline Mexico & 11 & 5.57 \\
\hline Korea, Rep. & 12 & 5.56 \\
\hline Indonesia & 16 & 5.21 \\
\hline Taiwan, China & 17 & 5.16 \\
\hline Australia & 19 & 5.10 \\
\hline Poland & 20 & 5.07 \\
\hline South Africa & 24 & 4.86 \\
\hline Egypt & 26 & 4.81 \\
\hline Malaysia & 28 & 4.70 \\
\hline Ukraine & 29 & 4.67 \\
\hline Colombia & 31 & 4.63 \\
\hline
\end{tabular}

\begin{tabular}{|l|c|c|}
\hline \multicolumn{1}{|c}{ Sweden } & 32 & 4.63 \\
\hline Greece & 34 & 4.59 \\
\hline Philippines & 35 & 4.57 \\
\hline Switzerland & 36 & 4.56 \\
\hline Venezuela & 37 & 4.55 \\
\hline Vietnam & 38 & 4.55 \\
\hline Singapore & 39 & 4.53 \\
\hline Portugal & 43 & 4.40 \\
\hline Chile & 44 & 4.39 \\
\hline Peru & 46 & 4.35 \\
\hline Denmark & 49 & 4.32 \\
\hline Finland & 53 & 4.23 \\
\hline New Zealand & 59 & 3.89 \\
\hline Guatemala & 71 & 3.57 \\
\hline Costa Rica & 77 & 3.41 \\
\hline El Salvador & 80 & 3.32 \\
\hline Honduras & 84 & 3.26 \\
\hline Luxembourg & 85 & 3.25 \\
\hline Bolivia & 87 & 3.24 \\
\hline Namibia & 113 & 2.57 \\
\hline & 1 & \\
\hline
\end{tabular}

\begin{tabular}{|l|c|c|}
\hline \multicolumn{2}{|c|}{ BUSINESS SOPHISTICATION } \\
\hline COUNTRY / ECONOMY & RANK & SCORE \\
\hline Japan & 1 & 5.89 \\
\hline Germany & 2 & 5.82 \\
\hline Switzerland & 3 & 5.81 \\
\hline Sweden & 4 & 5.66 \\
\hline United States & 5 & 5.65 \\
\hline Denmark & 8 & 5.51 \\
\hline Finland & 9 & 5.40 \\
\hline Taiwan, China & 13 & 5.22 \\
\hline Singapore & 14 & 5.20 \\
\hline Korea, Rep. & 21 & 4.91 \\
\hline Luxembourg & 22 & 4.85 \\
\hline Malaysia & 24 & 4.80 \\
\hline Australia & 26 & 4.79 \\
\hline India & 27 & 4.76 \\
\hline Brazil & 32 & 4.64 \\
\hline New Zealand & 34 & 4.64 \\
\hline South Africa & 36 & 4.57 \\
\hline China & 38 & 4.54 \\
\hline I I & & 1 \\
\hline
\end{tabular}

\begin{tabular}{|c|c|c|}
\hline Chile & 39 & 4.52 \\
\hline Indonesia & 40 & 4.49 \\
\hline Costa Rica & 41 & 4.48 \\
\hline Poland & 44 & 4.35 \\
\hline Guatemala & 47 & 4.32 \\
\hline Portugal & 53 & 4.28 \\
\hline Colombia & 60 & 4.17 \\
\hline Mexico & 62 & 4.15 \\
\hline El Salvador & 63 & 4.07 \\
\hline Philippines & 65 & 4.06 \\
\hline Greece & 66 & 4.04 \\
\hline Peru & 68 & 4.02 \\
\hline Vietnam & 70 & 4.00 \\
\hline Egypt & 72 & 3.98 \\
\hline Namibia & 86 & 3.75 \\
\hline Honduras & 87 & 3.72 \\
\hline Ukraine & 91 & 3.63 \\
\hline Russian Federation & 95 & 3.59 \\
\hline Bolivia & 131 & 3.04 \\
\hline Venezuela & 132 & 3.01 \\
\hline
\end{tabular}


Mexico in Asia Pacific: Lagging Competitiveness and Lacking Reform

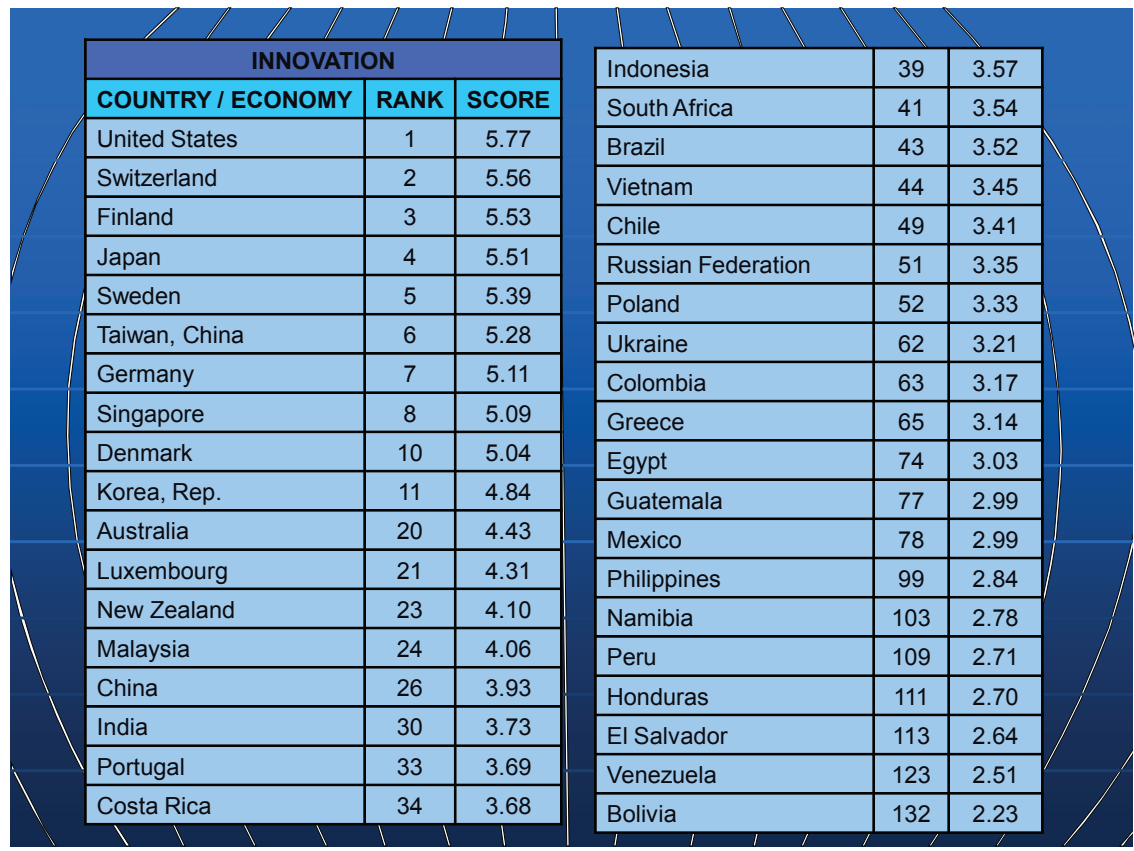

